\title{
Medication Misplaced
}

National Cancer Institute

\section{Source}

National Cancer Institute. Medication Misplaced. NCI Thesaurus. Code C102664.

Medications that were lost because they were put in the wrong place. 